\title{
Prevalensi Kesulitan Belajar Peserta Didik di Madrasah Aliyah Negeri I Bandar Lampung
}

\section{Defriyanto, Oki Dermawan}

\author{
Universitas Islam Negeri Raden Intan Lampung
}

Submitted: 20-04-2018, Revised: 06-06-2018, Accepted: 20-06-2018

\begin{abstract}
To improve the learning achievement of students in school, it is necessary to provide assistance that can overcome them in the learning process. But it is not easy. It is better to help learners in overcoming learning difficulties, the number of occurrences of participants who have learned difficulties. Measuring the prevalence of learning difficulties in madrasas is necessary, as this will be related to the diagnosis of learning difficulties and what programs are appropriate to learners. By knowing the prevalence of learning difficulties learners in madrasah, it will help teachers in providing appropriate assistance to these learners. Madrasah Aliyah Negeri I Bandar Lampung is a madrasah Aliyah which has a lot of students. Based on the results of interviews with teachers counseling and guidance in the madrasah there are numbers of students whose learning achievement are low and have difficulty learning (Interview with Miss Dina Kurniasih). The formulation of this research problem: How to profile students's learning difficulties in MAN I Bandar Lampung? and How much is the prevalence of learning difficulties in MAN I Bandar Lampung? Based on the results of data analysis, this study can be concluded that the prevalence of learning difficulties in Madrasah Aliyah Negeri I Bandar Lampung is 26, 2\%. The prevalence of learning difficulties is more prevalent in Gentelmant students than in female students. While the residence of students and departments does not determine the prevalence of learning difficulties. It may be said that place of residence and departement of students do not show differences in the prevalence of learning difficulties experienced of the students.
\end{abstract}

Keywords: Prevalence; difficulties; learn

\begin{abstract}
Abstrak: Untuk meningkatkan prestasi belajar peserta didik di sekolah, perlu diberikan bantuan-bantuan yang dapat mengatasi mereka dalam proses pembelajaran. Ada baiknya sebelum dilakukan upaya membantu peserta didik dalam mengatasi kesulitan belajar, perlu diketahui seberapa besar prevalensi (angka kejadian) peserta yang mengalami kesulitan belajar. Mengukur prevalensi kesulitan belajar di madrasah memang perlu dilakukan, karena hal ini akan berhubungan dengan diagnosis kesulitan belajar dan program apa yang tepat diberikan kepada peserta didik. Dengan mengetahui prevalensi kesulitan belajar peserta didik di madrasah, maka akan membantu guru dalam memberikan bantuan yang tepat kepada peserta didik tersebut. Madrasah Aliyah Negeri I Bandar Lampung merupakan madrasah Aliyah yang memiliki peserta didik yang sangat banyak. Berdasarkan hasil wawancara dengan guru bimbingan konseling di madrasah ini ada sejumlah siswa yang prestasi belajarnya rendah dan mengalami kesulitan belajar (Wawancara dengan ibu Dina Kurniasih). Adapun rumusan masalah penelitian ini: Bagaimana profil kesulitan belajar peserta didik di MAN I Bandar Lampung? dan Berapa besar prevalensi kesulitan belajar di MAN I Bandar Lampung? Berdasarkan hasil analisis data maka penelitian ini dapat disimpulkan bahwa prevalensi kesulitan belajar di Madrasah Aliyah Negeri I Bandar Lampung sebesar 26, $2 \%$. Prevalensi kesulitan belajar lebih banyak terjadi pada peserta didik laki-laki dari pada peserta didik perempuan. Sedangkan Tempat tinggal peserta didik dan jurusan tidak menentukan prevalensi kesulitan belajar. Boleh dikatakan bahwa tempat tinggal dan jurusan peserta didik tidak menunjukkan perbedaan prevalensi kesulitan belajar yang dialami oleh peserta didik tersebut.
\end{abstract}

Kata kunci: Prevalensi; kesulitan; belajar

\section{Pendahuluan}

Chosiyah, Syamsuri, dan Soekirman (2001: 39) merumuskan kesulitan belajar sebagai suatu gejala yang nampak pada anak dengan ditandai adanya prestasi atau hasil belajar yang rendah serta berada dibawah batas normal yang telah diterapkan. Dalam konteks pendidikan di sekolah prestasi peserta didik yang mengalami kesulitan belajar biasanya menempati kedudukan yang lebih rendah bila dibandingkan dengan prestasi belajar peserta didik lain yang tidak mengalami kesulitan belajar. Hal ini dipertegas oleh Muhibbin Syah bahwa fenomena 
kesulitan belajar peserta didik bisanya tampak jelas dari menurunya prestasi atau semangat kerja siswa(Muhibbin, 2005).

Secara nyata dapat juga kita katakan bahwa peserta didik yang prestasi belajarnya rendah tidak bisa pungkiri bahwa anak tersebut sesungguhnya sedang mengalami kesulitan belajar. Maka dari itu untuk meningkatkan prestasi belajar peserta didik di sekolah, peserta didik perlu diberikan bantuan-bantuan yang dapat mengatasi mereka dalam proses pembelajaran. Namun hal itu tidak mudah. Ada baiknya sebelum dilakukan upaya membantu peserta didik dalam mengatasi kesulitan belajar, perlu diketahui seberapa besar prevalensi (angka kejadian) peserta yang mengalami kesulitan belajar.

Mengukur prevalensi kesulitan belajar di sekolah/madrasah memang perlu dilakukan, karena hal ini akan berhubungan dengan diagnosis kesulitan belajar dan program apa yang tepat diberikan kepada peserta didik. Dengan mengetahui prevalensi kesulitan belajar peserta didik di sekolah atau madrasah, maka akan membantu guru dalam memberikan bantuan yang tepat kepada peserta didik yang mengalami kesulitan belajar(Brophy, 1999).

Madrasah Aliyah Negeri I Bandar Lampung merupakan madrasah Aliyah yang memiliki peserta didik yang sangat banyak. Berdasarkan hasil wawancara dengan guru bimbingan konseling di madrasah ini ada sejumlah siswa yang prestasi belajarnya rendah dan mengalami kesulitan belajar (Wawancara, Dina Kurniasih, 2017). Berdasarkan data awal ini maka perlu dilakukan penelitian lebih lanjut dengan judul penelitian Prevalensi Kesulitan Belajar Di Madrasah Aliyah Negeri I Bandar Lampung. Tujuan penelitian ini adalah untuk mengetahui prevalensi kesulitan belajar peserta didik di MAN I Bandar Lampung berdasarkan jurusan, jenis kelamin.

Kesulitan belajar merupakan terjemahan dari istilah bahasa Inggris Learning disability. Terjemahan tersebut sesungguhnya kurang tepat karena learning artinya belajar dan disability artinya ketidakmampuan, sehingga terjemahan yang benar seharusnya adalah ketidakmampuan belajar(Brophy, 1999). Kesulitan belajar pertama kali dikemukakan oleh The United State Office of Education (USOE) pada tahun 1977 yang dikenal dengan public Law, sebagaimana yang dikutip oleh Hallahan, Kauffman dan Lloyd sebagai berikut, kesulitan belajar khusus adalah suatu gangguan dalam dalam satu atau lebih dari proses psikologis dasar yang mencakup pemahaman dan penggunaan bahasa ujaran atau tulisan. Gangguan tersebut mungkin menampakkan diri dalam bentuk kesulitan mendengarkan, berfikir, berbicara, membaca, menulis, mengeja atau berhitung. Batasan tersebut mencakup kondisi-kondisi seperti gangguan perceptual, luka pada otak, disleksia dan afasia perkembangan. Batasan tersebut tidak mencakup anak-anak yang memiliki problema belajar yang penyebab utamanya berasal dari adanya hambatan dalam penglihatan, pendengaran ataumotorik, hambatan tuna grahita, karena gangguan emosional, atau karena kemiskinan lingkungan, budaya atau ekonomi (Abdurrahman, 2012).

Meskipun definisi USOE merupakan definisi resmi yang digunakan oleh pemeritah Amerika serikat, tetapi banyak kritik yang ditujukan terhadap definisi tersebut karena berbagai alasan. Ada beberapa kritikan yang muncul diantaranya dalam penggunaan istilah anak, proses psikologis dasar, pemisahan mengeja dari ekspresi pikiran dan perasaan secara tertulis adanya berbagai kondisi yang digabungkan menjadi satu dan pernyataan yang menyatakan bahwa kesulitan belajar dapat terjadi bersamaan dengan kondisi-kondisi lain. Jika kajian tentang kesulitan belajar juga mencakup orang dewasa maka perlu dihindari penggunaan istilah anak. Penggunaan 'proses psikologis dasar (basic psikologi process) dapat mengundang timbulnya perdebatan luas yang tidak ada gunanya dalam bidang kesulitan belajar(Abdurrahman, 2012).

Memasukkan mengeja sebagai teori yang terpisah adalah tidak pada tempatnya karena mengeja bagian yang tidak terpisahkan dari ekspresi fikiran dan perasaan secara tertulis. Definisi tersebut juga kurang bermutu karena adanya sederatan kondidi yang memasukkan gangguan perceptual, luka pada otak, disfungsi otak disfungsi otak minimal, disleksia dan 
afasia perkembangan(Corey, 2013). Definisi tersebut juga mengundang timbulnya kesalahpahaman yang luas karena kesulitan belajar dapat terjadi bersamaan dengan kondisikondisi penghambat laian atau tanpa adanya kemiskinan lingkungan, budaya atau ekonomi.

Hasil penelitian yang dilakukan oleh Tarmansyah, tahun 2003 terdapat 411 anak atau 11,28\% anak berkesulitan belajar di Sekolah Dasar se-Kecamatan Pauh Padang. Mereka mengalami masalah yang bervariasi. Ada yang hanya mengalami satu aspek gangguan atau kesulitan dan ada juga yang mengalami lebih dari satu aspek gangguan atau kesulitan. Dari hasil temuannya di setiap Sekolah. Dasar Kecamatan Pauh hampir dari jenjang kelas I s/d VI terdapat anak yang mengalami kesulitan belajar diantaranya 76,6\% mengalami kesulitan membaca, 75,3\% mengalami gejala lambat belajar, 66,4\% mengalami gejala under uchiever (prestasi di bawah rata-rata), 66,36\% mengalami kelemahan dalam mata pelajaran yang di ebtanaskan, $61,3 \%$ mengalami kesulitan dalam menulis dan 48,6\% mengalami kesulitan dalam berhitung. Siswa-siswa tersebut mengalami masalah dalam bidang akademik dan memerlukan layanan pendidikan khusus. Jika anak berkesulitan belajar tersebut tidak mendapatkan layanan khusus bisa kita bayangkan saja berapa banyak siswa yang akan terancam tinggal kelas bahkan beresiko tinggi bisa putus sekolah.

Hasil penelitian oleh Mulyono misalnya menyebutkan bahwa guru se DKI menyatakan bahwa terdapat $16.52 \%$ dari 3.215 siswa mengalami kesulitan belajar. Atau seperti yang disampaikan oleh Kazuhiko bahwa prevalensi kesulitan bejar adalah dalam rentangan $1 \%$ hingga $4 \%$, dengan perbandingan anak laki-laki dengan anak perempuan 4 berbanding 1 hingga 7 berbanding 1 . Menurut Lerner $40 \%$ dari anak berkebutuhan khusus yang memperoleh layanan PLB di Amerika Serikat ialah anak-anak yang tergolong berkesulitan belajar. Perbandingan proporsi mereka antara anak laki-laki dengan anak perempuanadalah 72 berbanding 78. Data tersebut menunjukkan bahwa kesulitan belajar lebih banyak terjadi pada anak laki-laki dari pada anakperempuan.

Menurut Hallan anak berkesulitan belajar meningkat secara dramatic dan sebalinya jumlah anak tunagrahitamenurun tajam. Keadaan semacam itu terjadi sekitar tahun 1980 an yaitu ketikakriteria adaptabilitas social digunakan untuk menentukan anak tunagrahita. Dengan digunakannya criteria adaptabilitas social di samping taraf intelegensi untuk mengidentifikasi anak tunagrahita, maka anak-anak yang pada mulanya termasuk kategori tunagrahita ternyata termasuk anak berkesulitan belajar.

Berdasarkan analisa yang dilakukan oleh Lerner perubahan prevalensi kesulitan belajar disebabkan oleh beberapa hal seperti peningkatan prosedur identifikasi dan asesmen anak berkesulitan belajar, persyarartan yang longgar untuk menetapkan anak yang berkesulitan belajar, orang tua dan guru lebih memilih klasifikasi anak beresulitan belajar daripada klisifikasi lain, penurunan biaya pendidikan pendidikan program khusus yang segregratif dan peningkatan biaya program PLB yang integrative inklusif, adanya evaluasi ulang terhadap anak yang pada mulanya dinyatakan sebagai anak tunagrahita.

Membuat klasifikasi kesulitan belajar sangat penting dilakukan agar penyelenggara pendidikan atau guru dapat memberikan strategi pembelajaran yang tepat untuk peserta didik yang mengalami kesulitan belajar. Namun ini tidak mudah dilakukan, mengingat kesulitan belajar bersifat heterogen.

Mulyono Abdurrahman mengklasifikaan kesulitan belajar ke dalam dua kelompok yaitu kesulitan belajar yang berhubungan dengan perkembangan (developmental learning disabilities) dan kesulitan belajar yang berhubungan dengan akademik (academic learning disabilities). Kesulitan belajar yang berhubungan dengan perkembangan dapat berupa gangguan motorik dan persepsi, kesulitan belajar bahasa dan penyesuaian perilaku sosial. Kesulitan belajar dalam hal akademik dapat terlihat dari kurangnya pencapaian prestasi akademik yang terdiri dari kegagalan dalam menguasai keterampilan membaca, menulis dan atau matematika(Abdurrahman, 2012). 
Pada saat sekarang ini terlihat bahwa anak berkesulitan belajar yang ada di setiap Sekolah Dasar kurang mendapat perhatian dari pemeri ntah karena dinas setempat itu sendiri terkadang tidak mengetahui berapa jumlah yang pasti anak berkesulitan belajar di setiap sekolah. Dinas setempat kurang menerima laporan berapa jumlah anak berkesulitan belajar di setiap sekolah yang ada karena pihak sekolah seperti kepala sekolah dan para guru jarang sekali mengidentifikasi anak yang berkesulitan belajar yang berada di setiap sekolah, akibatnya mereka tidak mengetahui seberapa banyak anak berkesulitan belajar yang ada saat ini.

\section{Metode Penelitian}

Pendekatan yang peneliti gunakan dalam penelitian ini adalah pendekatan kuantitatif deskriptif. Peneliti Metodologi dalam penelitian ini bersifat deskriptif dengan pendekatan kuantitatif. Populasi dalam penelitian ini adalah seluruh peserta didik Kelas X di MAN I Bandar Lampung yang terdiri dari 4 jurusan yaitu jurusan Matematika Ilmu Alam (MIA), IlmuIlmu Sosial (IIS), Ilmu-Ilmu Bahasa (IIB), Ilmu-Ilmu Keagamaan. Jurusan MIA terdiri dari 5 kelas, jurusan IIS terdapat 4 kelas, jurusan IIB terdiri dari 1 kelas dan jurusan IIK ada 2 kelas. Secara keseluruhan terdapat 12 kelas di kelas X MAN I Bandar Lampung. Pengambilan sampel dilakukan secara acak (random). Alasan peneliti menggunakan teknik random dalam memilih sampel dalam penelitian ini agar setiap peserta emilii didik kelas x di MAN I Bandar Lampung memiliki peluang yang sama untuk diplih menjadi sampel. Selain itu peneliti berupaya menimalisir bias dalam penelitian ini.

Secara spesifik peneliti menggunakan tekhnik simple random sampling berbentuk replacement. Pelaksanaan teknik ini dilakukan dengan cara setiap sampel yang terpilih dikembalikan ke dalam kelompok populasi(Creswell, 2007). Diharapkan dengan cara seperti ini setiap peserta didik memilki peluang yang sama untuk terpilih sebagai sampel. Dengan demikian jumlah populasi tetap sama sehingga jumlah sampel sampai kepada jumlah yang sesuai dengan kriteria yang diharapkan dalam penelitian ini. Pada penelitian ini peneliti menggunakan Kuisioner sebagai teknik pengumpulan data. Kuisioner digunakan dalam penelitian ini agar data yang dibutuhkan dapat diperoleh dalam waktu yang relatif singkat, dengan biaya yang lebih rendah, namun data dapat diperoleh lebih banyak.

Kuisioner dalam penelitian ini memuat beberapa indikator yang akan mengukur tingkat kesulitan belajar peserta didik, yang mana indikator tersebut menggambarkan proses belajar peserta didik dan hal-hal yang terkait dengan proses pembelajaran. Kuisioner dalam penelitian ini berbentuk terbuka dan tertutup. Penggunaan instrument dengan dua bentuk ini memiliki kelebihan dan kekurangan, sehingga dapat mengimbangi kelemahan salah satu bentuk yang ada. Dengan demikian data yang didapatkan dari dua bentuk kuisioner yang berbeda bisa saling melengkapi dan memperkuat data yang ada. Banyak kelebihan yang dapat diperoleh dari penggunaan kuisioner tertutup, sebagaimana yang telah diuraikan oleh A. Muri Yusuf(2004;203), sebagai berikut :

a. Alternative jawaban yang diberikan terstruktur dan sama antara yang satu dengan yang lainnya. Kontaminasi aspek yang lainnya dapat diurangi.

b. Peneliti dapat meng-"cover" lokasi yang luas dan tersebar.

c. Mempunyai instruksi yang seragam sehingga mengurangi subjektivitas peneliti saat pengumpulan data.

d. Kuisioner lebih mudah diadministrasikan daripada instrumen yang lain, seperti tes dan interviu.

e. Biaya yang digunakan relatif murah daripada instrumen yang lain.

f. Dapat dipebandingkan antara jawaban satu responden dengan responden yang lain.

g. Jawaban yang diberikan responden mudah diproses karena alternative jawaban telah tersruktur. 
h. Arti jawaban yang dikemukakan dalam kuisioner lebih jelas bagi responden, karena dibantu oleh alternatif jawaban yang disediakan.

i. Lebih sedikit jawaban yang kurang relevan, baik ditinjau dari segi isi maupun dikaitkan dengan kondisi responden.

j. Lebih mudah responden menjawabnya

k. Mudah diberi kode

Kelebihan kuisioner tertutup ter dapat juga beberapa kekurangan kuisioner tertutup ini, berikut dikutip beberapa kekurangan kuisioner tertutup menurut A. Muri Yusuf(Yusuf, 2014):

a. Cara menentukan validitas dan reliabilitas instrument masih terbatas.

b. Rendahnya pengembalian instrument akan menyebabkan ancaman validitas instrument.

c. Vailiditas instrumen tergantung pada kemampuan dan kemauan responden dalammenyediakan informasi

d. Adanya kemungkinan terjadinya salah tafsir terhadap terhadap pertanyaan oleh responden.

e. Menghilangkan dan/atau membatasi hal-hal yang bersifat personal dari responden sehingga sering menimbulkan kekecewaan. Kadang-kadang jawaban yang disediakan tidak berkenan di hati responden

f. Mudah diterka oleh responden

g. Terlalu banyakkategori jawaban sehingga banyak membutuhkan tempat dan fasilitas

h. Perbedaan intrepretasi tentang pertanyaan tidak dapatdikketahui dengan jelas karena tidakadanya tidak lanjut tambahan klarifikasi dan intrepretasi.

i. Perbedaaan jawaban diantara responden yang ada menjadi hilang dengan menciptakan situasi artifisial dan alternative respon yang terbatas.

Skala penelitian sebenarnya masih bagian dari instrumen penelitian, yang mana skala biasana ditemukan di alat yang digunakan dalam pengumpulan data. Sebagaimana yang dapat dilihat dalam sebuah kuisioner misalnya terdapat berbagai macam skala yang dapat digunakan oleh peneliti. Pemilihan tipe skala yang digunakan sangat penting sekali diperhatikan untuk keakuratan data penelitian, oleh karena itu hal yang harus diperhatikan terkait skala yang akan digunakan adala jenis data apakah yang dibutuhkan dalam satu penelitian(Emzir, 2004).

Maka dari itu dalam penelitian ini, Kuisioner dalam penelitian ini menggunakan skala likert dan skala Gutman. Skala likert dalam kuisioner terdiri dari 4 pilihan jawaban yaitu jawaban yait: (1) sering, (2) kadang-kadang, (3) pernah, dan (4), tidak pernah. Untuk pernyataan positif jawaban sering memperoleh skor 4 , jawaban pernah diberi skor 3 , jawaban kadang-kadang dengan skor 2 dan jawaban tidak pernah diberi skor 1 . Untuk pernyataan negatif jawaban sering diberi skor 1 , pernah skor 2, kadang-kadang dengan skor 4 dan tidak pernah dengan skpr 4.

Ada 3 kategori prevalensi kesulitan belajar yang ditetapkan dalam penelitian ini berdasarkan skor yang diperoleh berdasarkan kuisioner yang dijawab oleh responden, seperti tabel 1 di bawah ini:

\begin{tabular}{|c|c|c|}
\hline No & Rentang Skor & Kategori \\
\hline 1 & $0-16$ & Rendah \\
\hline 2 & $17-33$ & Sedang \\
\hline 3 & 34- 48 & Tinggi \\
\hline
\end{tabular}

Tujuan penelitian ini adalah untuk mengetahui prevalensi kesulitan belajar peserta didik di MAN I Bandar Lampung berdasarkan jurusan, jenis kelamin 


\section{Hasil dan Pembahasan}

Profil Responden Berdasarkan Jenis Kelamin

Tabel 1. Data Jenis Kelamin Responden

\begin{tabular}{lcccc}
\hline Responden & Frekuensi & \% & Valid Persen & Kumulatif Persen \\
\hline Laki-laki & 28 & 66.7 & 66.7 & 66.7 \\
Perempuan & 14 & 33.3 & 33.3 & 100.0 \\
Total & 42 & 100.0 & 100.0 & \\
\hline
\end{tabular}

Berdasarkan tabel: 1 dapat diketahui bahwa jumlah secara keseluruhan berjumlah 42 orang, yang terdiri dari 28 orang $(66,7 \%)$ responden laki-laki. Responden perempuan berjumlah 14 orang $(33,3 \%)$. Perbedaan lebih jelas terlihat pada grafik 1 di bawah ini :

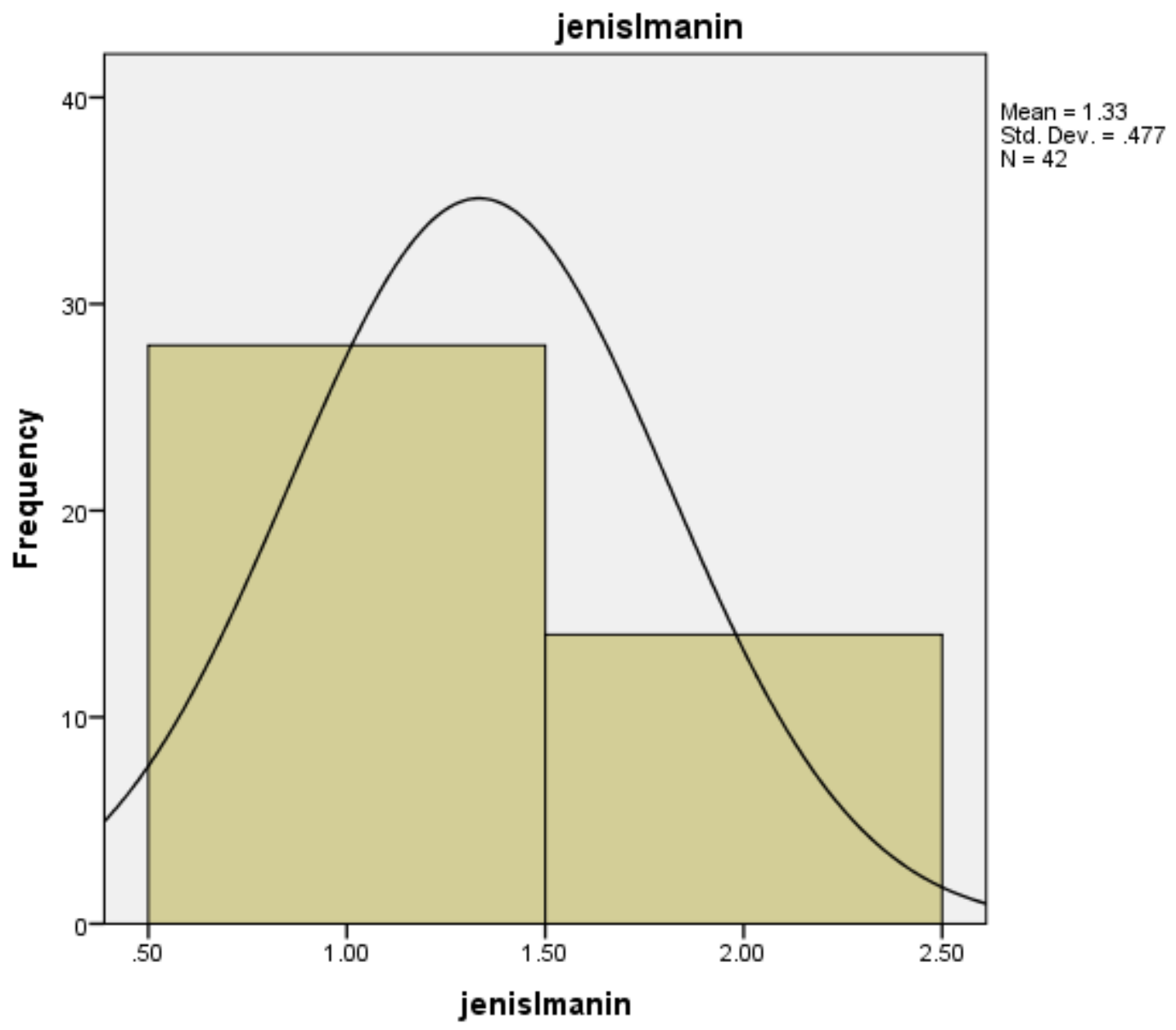

Gambar 1. Grafik Responden Berdasarkan JenisKelamin 
Tabel 2. Data Responden Berdasarkan Tempat Tingal

\begin{tabular}{lcccc}
\hline & Frequency & Percent & Valid Percent & Cumulative Percent \\
\hline ROTS & 13 & 31.0 & 31.0 & 31.0 \\
ROTA & 5 & 11.9 & 11.9 & 42.9 \\
RS & 3 & 7.1 & 7.1 & 50.0 \\
ASRAMA & 6 & 14.3 & 14.3 & 64.3 \\
TEMPAT KOST & 11 & 26.2 & 26.2 & 90.5 \\
KONTRAKAN & 4 & 9.5 & 9.5 & 100.0 \\
Total & 42 & 100.0 & 100.0 & \\
\hline
\end{tabular}

Data pada tabel 2 menunjukkan data responden berdasarkan tempat tinggal. Mayoritas responden bertempat tinggal di rumah orang tua sendiri yaitu sebanyak 13 orang $(31 \%)$. Responden yang bertempat tinggal di rumah kost juga termasuk tinggi 11 orang (26,2 5). Responden yang bertempat tinggal di rumah saudaara sebanyak 3 orang $(7 \%)$ merupakan paling rendah. Secara lebih rinci dapat di lihat pada Grafik 3 di bawah ini :

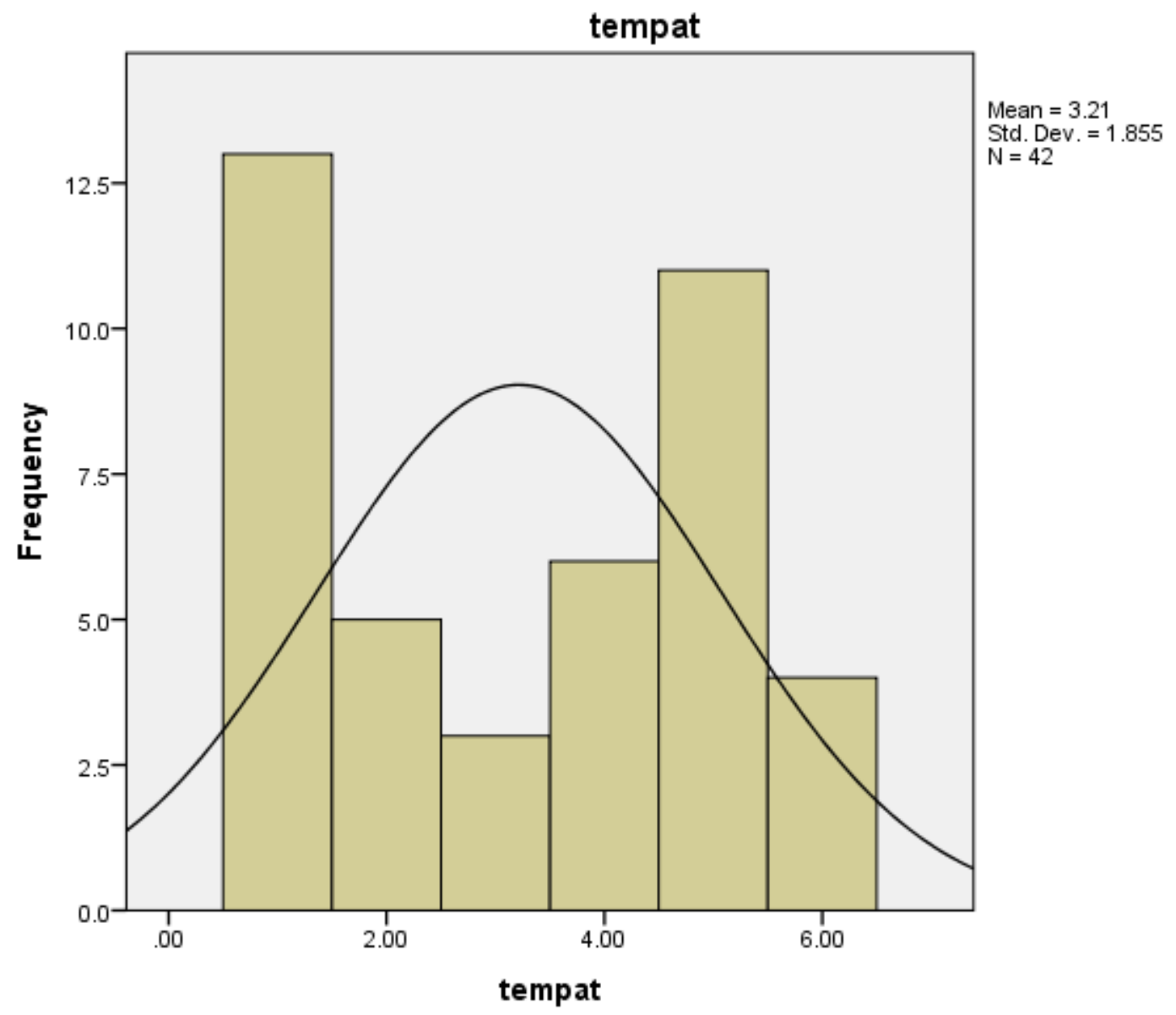

Gambar 2. Grafik Responden Berdasarkan Tempat Tinggal

Tabel 4. Data responden berdasarkan jurusan

\begin{tabular}{ccccc}
\hline & \multicolumn{5}{c}{ FrequencyPercent Valid Percent Cumulative Percent } \\
\hline ValidIIA & 13 & 31.0 & 31.0 & 31.0
\end{tabular}




$\begin{array}{lcccc}\text { IIS } & 11 & 26.2 & 26.2 & 57.1 \\ \text { IIB } & 5 & 11.9 & 11.9 & 69.0 \\ \text { IIK } & 13 & 31.0 & 31.0 & 100.0 \\ \text { Total } & 42 & 100.0 & 100.0 & \end{array}$

Tabel 4 menunjukkan data responden berdasarkan jurusan. Responden jurusan Ilmu-ilmu keagamaan berjumlah 13 orang (31\%). Responden yang berasal dari jurusan Ilmu-ilmu alam berjumlah13 orang (31\%). Kemudian responden jurusan Ilmu-ilmu sosial berjumlah 11 orang (26,2 5). Sedangkan responden Ilmu-ilmu bahasa berjumlah 5 orang (11,9\%). Grafik 4 di bawah ini terlihat perbedaan jumlah masing-masing responden berdasarkan jurusan ;

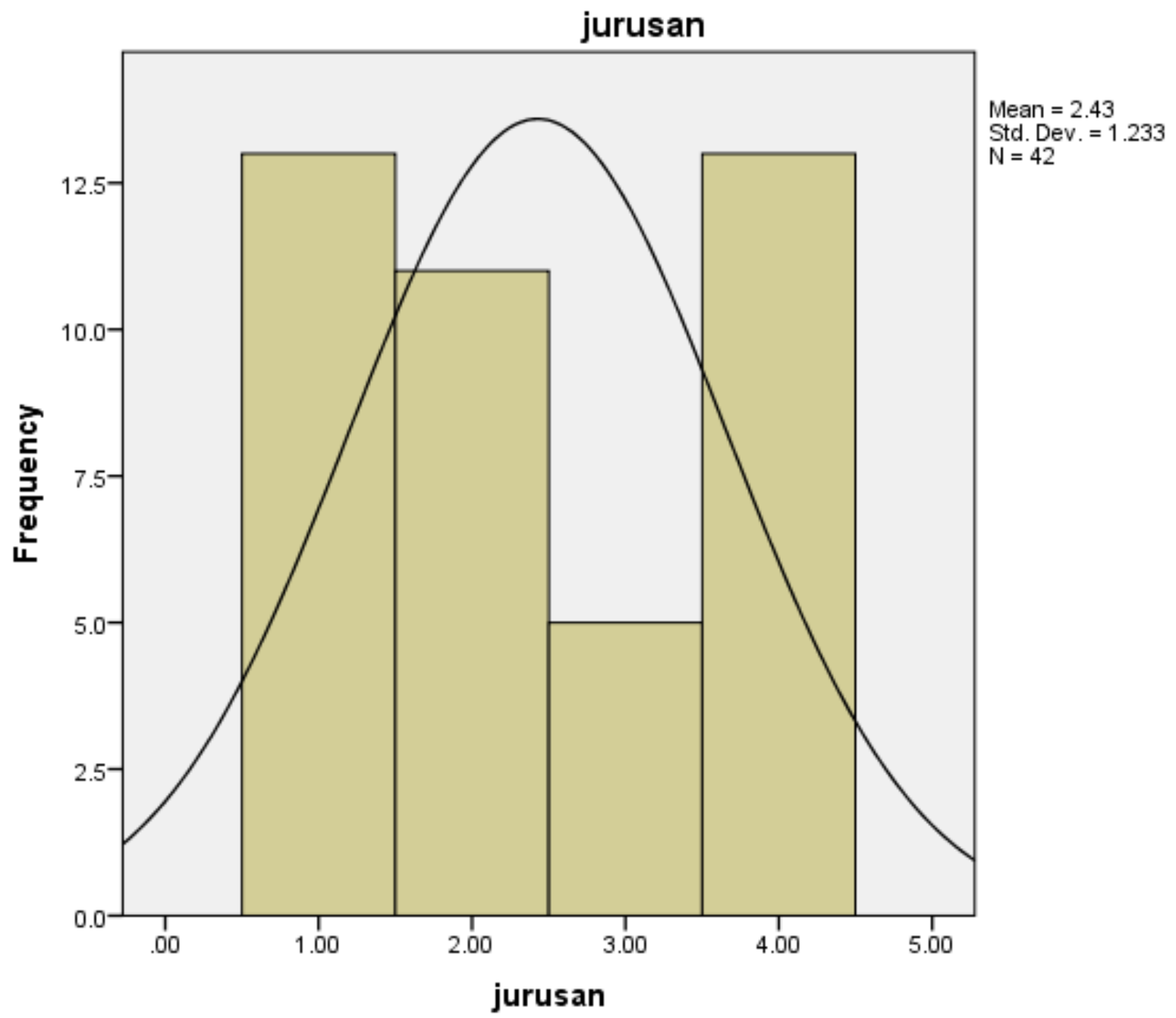

Gambar 3. Grafik Jurusan Responden

Tabel 5. Data Prevalensi Kesulitan Belajar Responden

\begin{tabular}{ccccc}
\hline \multicolumn{5}{c}{ FrequencyPercent Valid PercentCumulative Percent } \\
\hline ValidTinggi & 1 & 2.4 & 2.4 & 2.4 \\
Sedang & 30 & 71.4 & 71.4 & 73.8 \\
Rendah & 11 & 26.2 & 26.2 & 100.0 \\
Total & 42 & 100.0 & 100.0 & \\
\hline
\end{tabular}


Berdasarkan tabel 5 dapat diketahui bahwa dari 42 orang respnden dalam penelitian ini terdapat 11 orang ( $26 \%$ ) responden mengalami kesulitan belajar dengan kategori rendah. Kemudian sebanyak 30 orang $(71,4 \%)$ responden mengalami kesulitan belajar kategori sedang. Secara keseluruhan sebanyak 41 orang $(97,6 \%)$ responden mengalami kesulitan belajar.

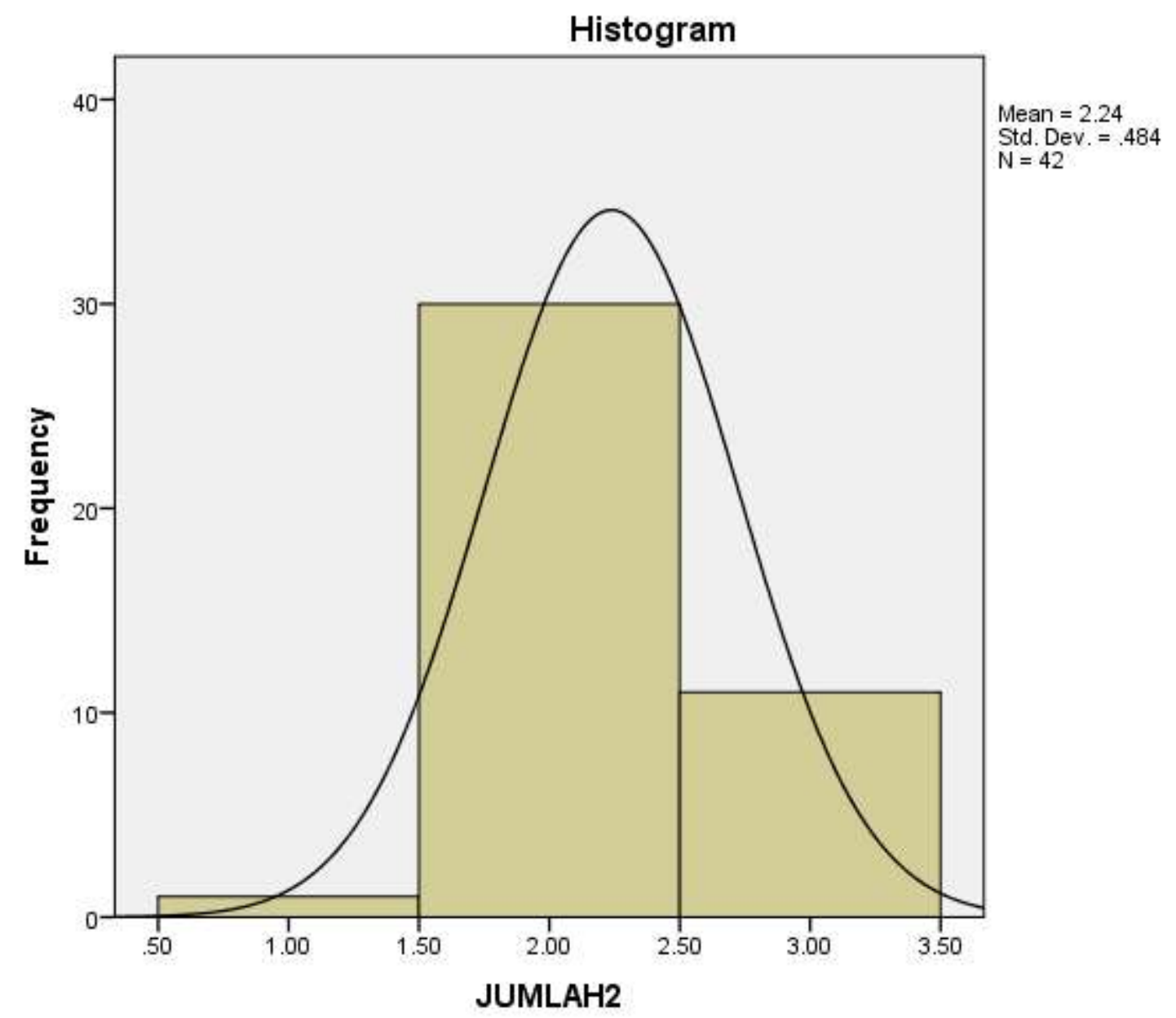

Grafik 4. Responden mengalami kesulitan belajar kategori

Tabel 5. Data Prevalensi Kesulitan Belajar Berdasarkan Jenis Kelamin

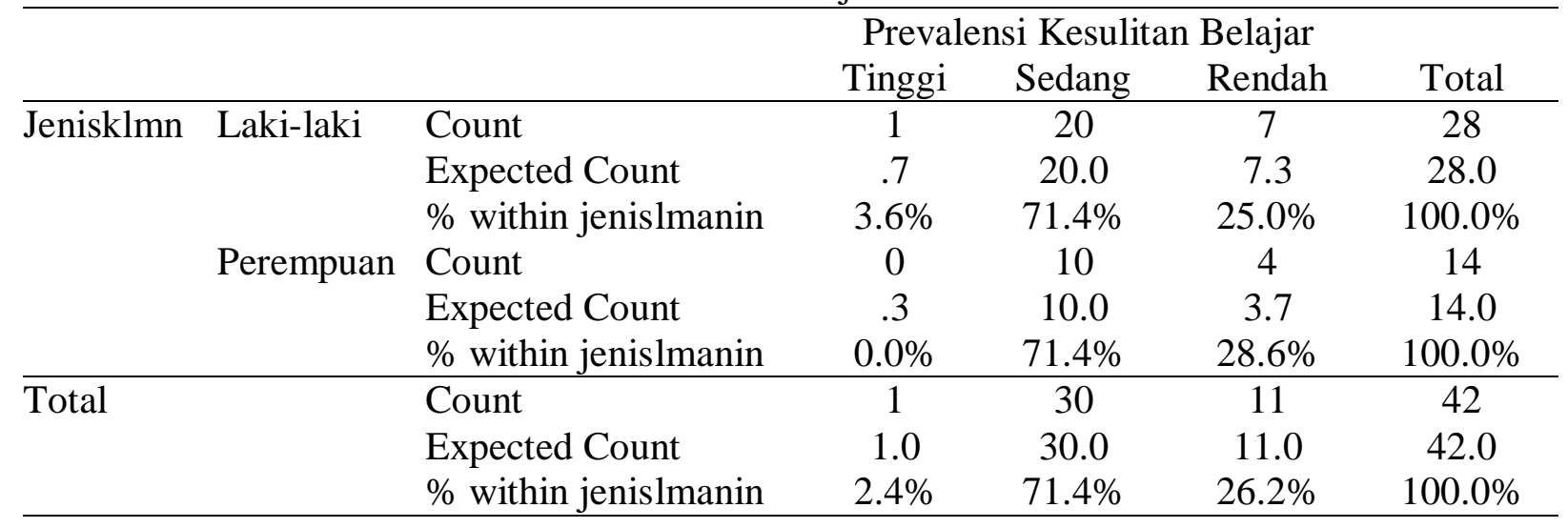

Data pada tabel 5 menunjukkan bahwa terdapat 20 orang $(71,4 \%)$ responden laki-laki yang mengalami kesulitan belajar dengan kategori sedang sebanyak 7 orang (25\%). Sedangkan 
responden perempuan yang mengalami kesulitan belajar dengan kategori sedang 10 orang $(71,4 \%)$. Dan responden perempuan yang mengalami kesulitan belajar dengan kategori rendah sebanyak 4 orang $(28,6 \%)$. Secara keseluruhan prevalesi kesulitan belajar responden berada pada kategori sedang $(71,4 \%)$, sebagaimana terlihat pada grafik 5 dibawah ini :

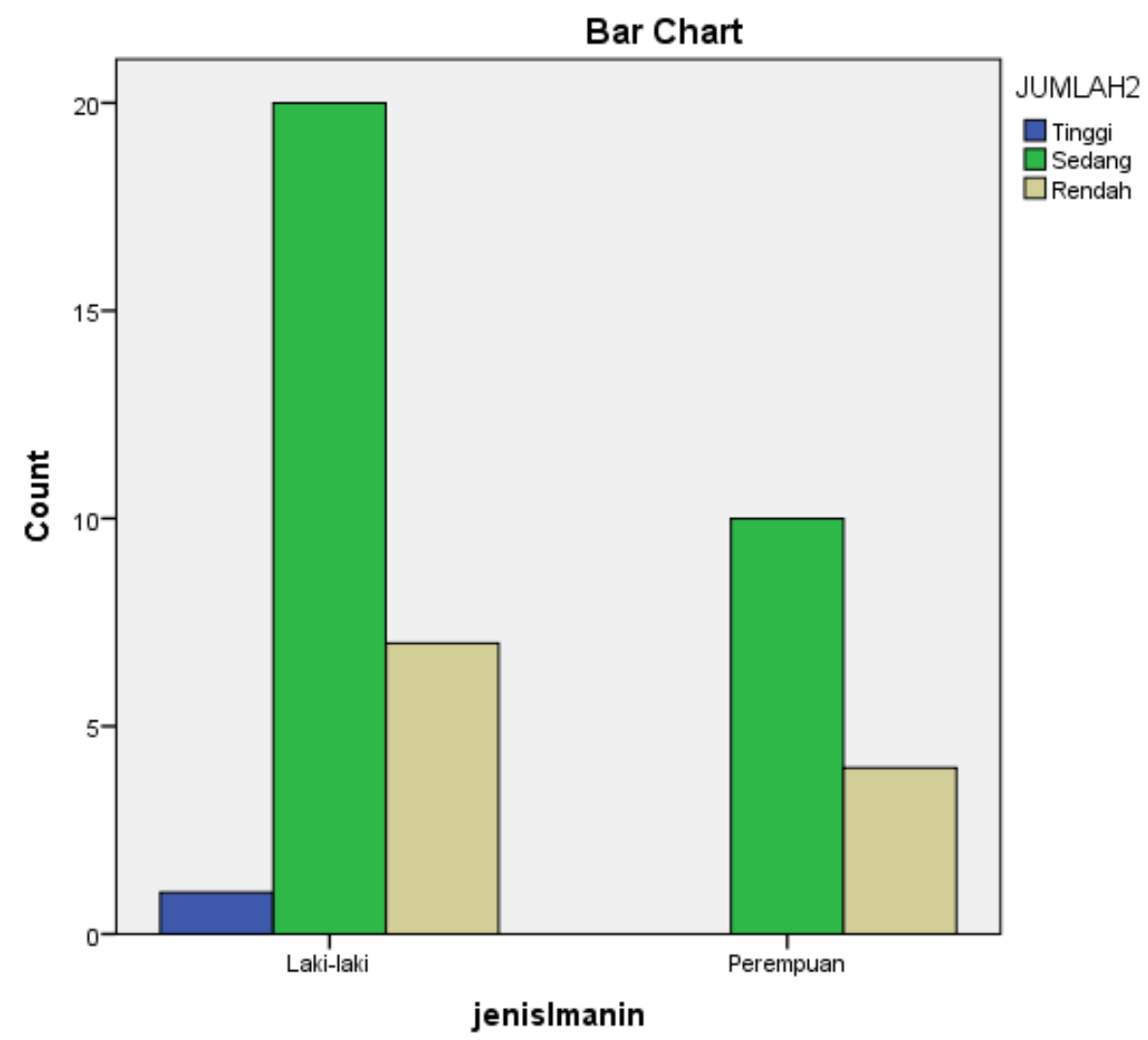

Gambar 5. Grafik prevalesi kesulitan belajar

Tabel 6. Data Prevalensi Kesulitan Belajar Berdasarkan Tempat Tinggal

\begin{tabular}{|c|c|c|c|c|c|c|}
\hline & & & Prev: & asi Kesul & Belajar & \\
\hline & & & Tinggi & Sedang & Rendah & Total \\
\hline Tempat & ROTS & Count & 0 & 9 & 4 & 13 \\
\hline & & Expected Count & .3 & 9.3 & 3.4 & 13.0 \\
\hline & & $\%$ within tempat & $0.0 \%$ & $69.2 \%$ & $30.8 \%$ & $100.0 \%$ \\
\hline & ROTA & Count & 0 & 3 & 2 & 5 \\
\hline & & Expected Count & .1 & 3.6 & 1.3 & 5.0 \\
\hline & & $\%$ within tempat & $0.0 \%$ & $60.0 \%$ & $40.0 \%$ & $100.0 \%$ \\
\hline & $\mathrm{RS}$ & Count & 0 & 3 & 0 & 3 \\
\hline & & Expected Count & .1 & 2.1 & .8 & 3.0 \\
\hline & & $\%$ within tempat & $0.0 \%$ & $100.0 \%$ & $0.0 \%$ & $100.0 \%$ \\
\hline & ASRAMA & Count & 0 & 4 & 2 & 6 \\
\hline & & Expected Count & .1 & 4.3 & 1.6 & 6.0 \\
\hline & & $\%$ within tempat & $0.0 \%$ & $66.7 \%$ & $33.3 \%$ & $100.0 \%$ \\
\hline & TEMPAT & Count & 1 & 7 & 3 & 11 \\
\hline & KOST & Expected Count & .3 & 7.9 & 2.9 & 11.0 \\
\hline & & $\%$ within tempat & $9.1 \%$ & $63.6 \%$ & $27.3 \%$ & $100.0 \%$ \\
\hline & & Count & 0 & 4 & 0 & 4 \\
\hline
\end{tabular}




\begin{tabular}{|c|c|c|c|c|c|c|}
\hline & $\begin{array}{l}\text { KONTRA } \\
\text { KAN }\end{array}$ & $\begin{array}{l}\text { Expected Count } \\
\% \text { within tempat }\end{array}$ & $\begin{array}{c}.1 \\
0.0 \%\end{array}$ & $\begin{array}{c}2.9 \\
100.0 \%\end{array}$ & $\begin{array}{c}1.0 \\
0.0 \%\end{array}$ & $\begin{array}{c}4.0 \\
100.0 \%\end{array}$ \\
\hline Total & & $\begin{array}{l}\text { Count } \\
\text { Expected Count } \\
\% \text { within tempat }\end{array}$ & $\begin{array}{c}1 \\
1.0 \\
2.4 \%\end{array}$ & $\begin{array}{c}30 \\
30.0 \\
71.4 \%\end{array}$ & $\begin{array}{c}11 \\
11.0 \\
26.2 \%\end{array}$ & $\begin{array}{c}42 \\
42.0 \\
100.0 \%\end{array}$ \\
\hline
\end{tabular}

Data pada tabel 6 menunjukkan bahwa prevalensi kesulitan belajar terbanyak dialami oleh responden yang bertempat tinggal di rumah orang tua sendiri yaitu sebanyak 13 orang dengan rincian 69,2 \% termasuk prevalensi kesulitan belajar kategori sedang dan 30,8 \% termasuk prevalensi kesulitan belajar kategori rendah.

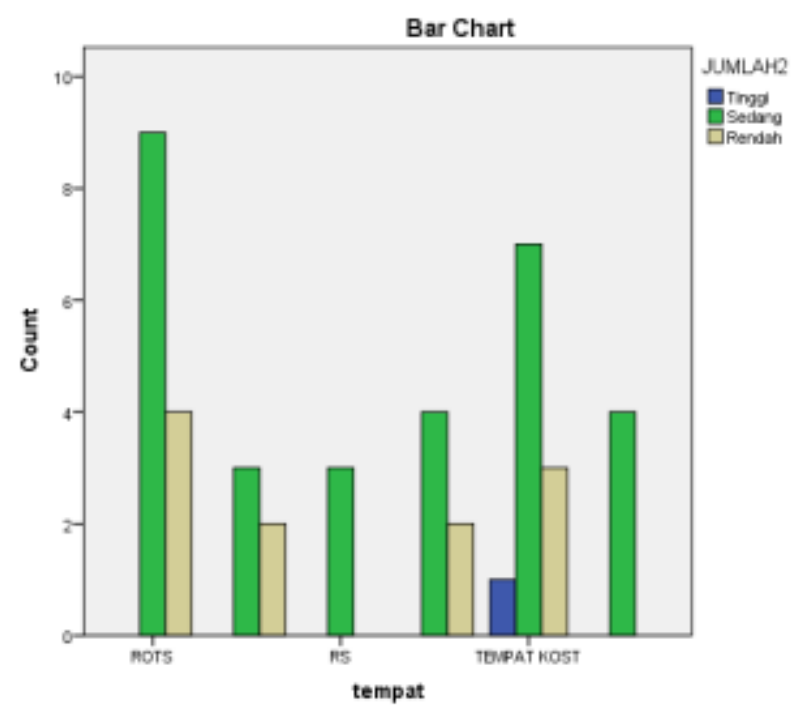

Gambar 6. Grafik prevalensi kesulitan belajar

Tabel 7. Data Prevalensi Kesulitan Belajar Responden Berdasarkan Jurusan

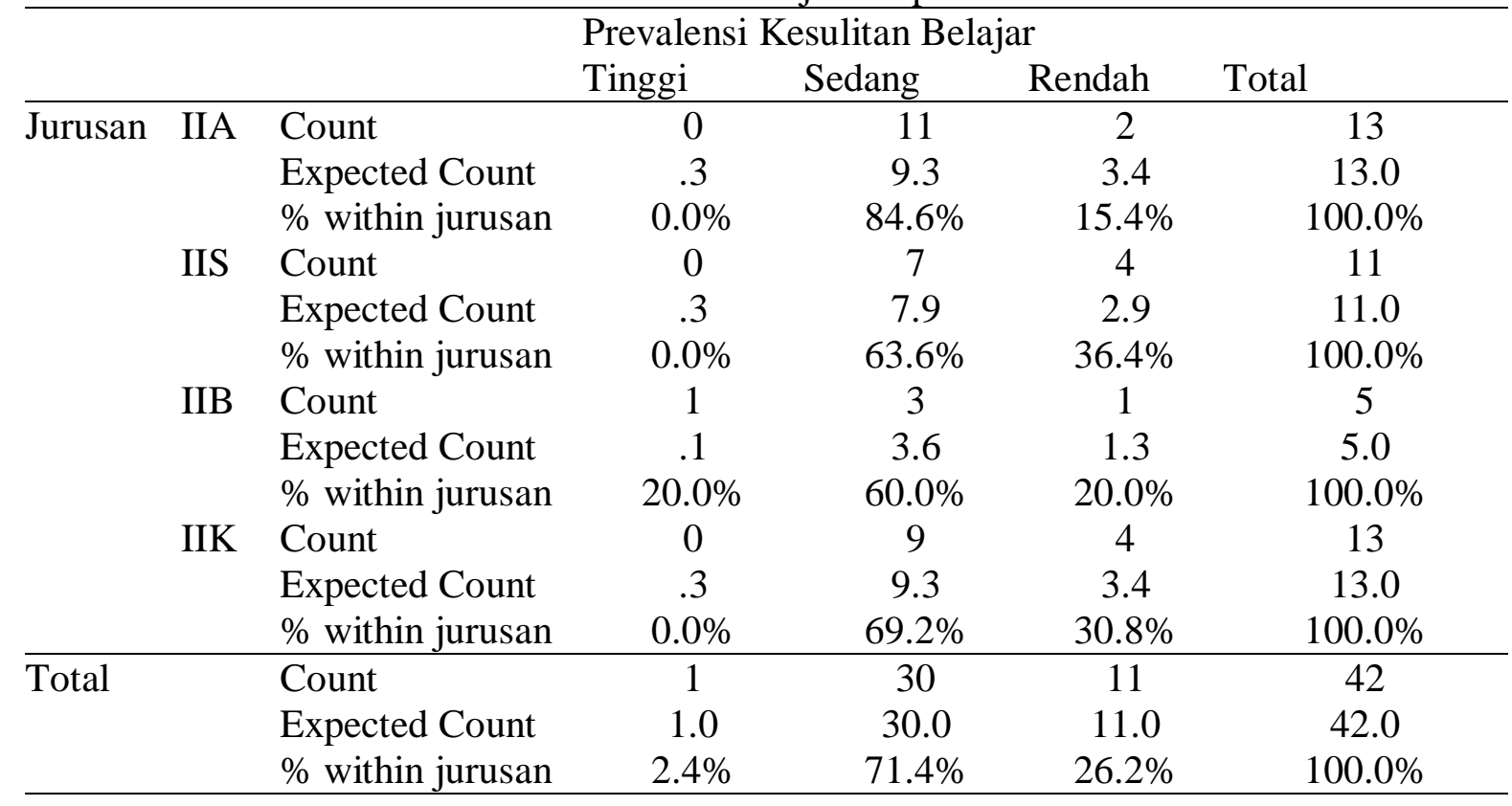


Data pada tabel 7 di atas menunjukkan prevalensi kesulitan belajar responden terbesar didominasi oleh responden dari jurusan Ilmu-ilmu alam dan responden dari jurusan ilmu-ilmu keagamaan dengan jumlah masing-masing 13 orang. Prevalensi terendah terjadi di jurusan ilmu-ilmu bahasa yaitu sebanyak 5 orang. Grafik 7 di bawah ini terlihat perbedaan prevalensi dari masing-masing jurusan:

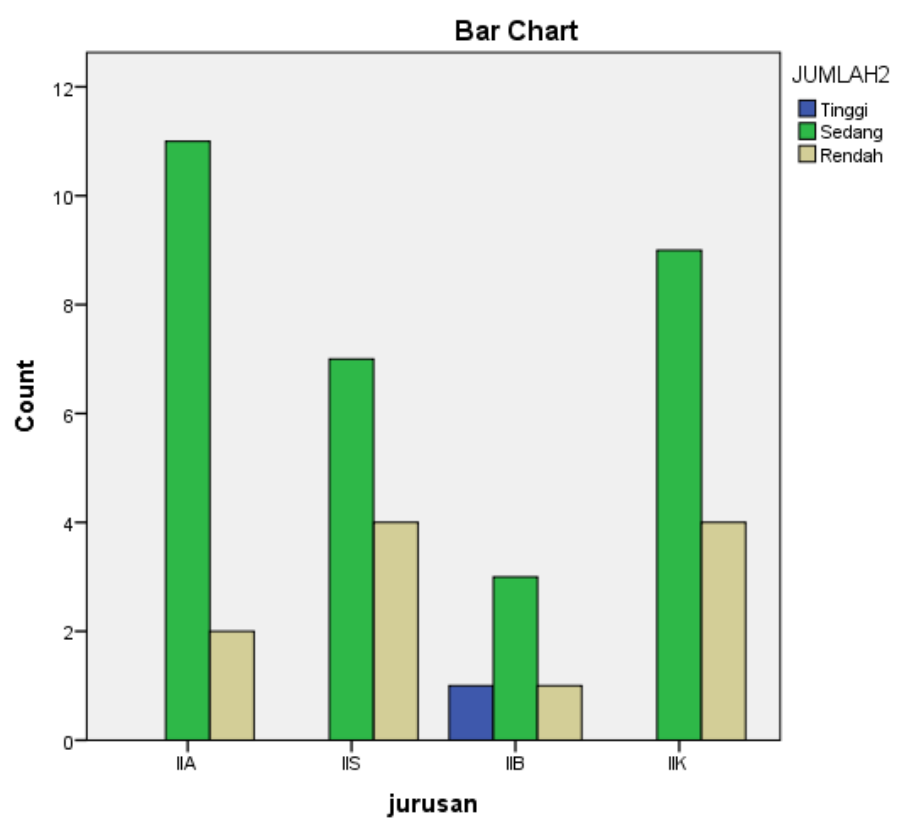

Gambar 7. Grafik prevalensi dari masing-masing jurusan

Sebagaimana telah dibahas pada bab sebelumnya bahwa para ahli berbeda pendapat dalam mendefenisikan kesulitan belajar. Bahkan tidak hanya itu saja, para ahli juga menggunakan berbagaimacam instrumen dalam mengukur kesulitan belajar. Oleh karena itu tidak mengherankan jika temuan tentang prevalensi kesulitan belajar yang berbeda-beda antara satu peneliti dengan peneliti lainnya.Sebagian ahli berpendapat bahwa prevalensi kesulitan belajar itu berkisar antara $1 \%$ hingga $30 \%$. Namun ada pula yang mengatakan kisaranya antara $2 \%$ hingga $30 \%$. Hasil penelitian oleh Mulyono misalnya menyebutkan bahwa guru se DKI menyatakan bahwa terdapat $16.52 \%$ dari 3.215 siswa mengalami kesulitan belajar. Atau seperti yang disampaikan oleh Kazuhiko bahwa prevalensi kesulitan belajar adalah dalam rentangan $1 \%$ hingga $4 \%$, dengan perbandingan anak laki-laki dengan anak perempuan 4 berbanding 1 hingga 7 berbanding 1 .

Menurut Hallan (Mulyono: 2012) anak berkesulitan belajar meningkat secara dramatis dan sebaliknya jumlah anak tunagrahita menurun tajam. Keadaan semacam itu terjadi sekitar tahun 1980 an yaitu ketikakriteria adaptabilitas sosial digunakan untuk menentukan anak tunagrahita. Dengan digunakannya kriteria adaptabilitas sosial di samping taraf intelegensi untuk mengidentifikasi anak tunagrahita, maka anak-anak yang pada mulanya termasuk kategori tunagrahita ternyata termasuk anak berkesulitan belajar.

Berdasarkan analisa yang dilakukan oleh Lerner perubahan prevalensi kesulitan belajar disebabkan oleh beberapa hal seperti peningkatan prosedur identifikasi dan asesmen anak berkesulitan belajar, persyarartan yang longgar untuk menetapkan anak yang berkesulitan belajar, orang tua dan guru lebih memilih klasifikasi anak beresulitan belajar daripada 
klisifikasi lain, penurunan biaya pendidikan pendidikan program khusus yang segregratif dan peningkatan biaya program PLB yang integrative inklusif, adanya evaluasi ulang terhadap anak yang pada mulanya dinyatakan sebagai anak tunagrahita.

Hasil penelitian yang dilakukan oleh Tarmansyah, tahun 2003 terdapat 411 anak atau 11,28\% anak berkesulitan belajar di Sekolah Dasar se-Kecamatan Pauh Padang. Mereka mengalami masalah yang bervariasi. Ada yang hanya mengalami satu aspek gangguan atau kesulitan dan ada juga yang mengalami lebih dari satu aspek gangguan atau kesulitan. Dari hasil temuannya di setiap Sekolah. Dasar Kecamatan Pauh hampir dari jenjang kelas I s/d VI terdapat anak yang mengalami kesulitan belajar diantaranya 76,6\% mengalami kesulitan membaca, 75,3\% mengalami gejala lambat belajar, 66,4\% mengalami gejala under uchiever (prestasi di bawah rata-rata), 66,36\% mengalami kelemahan dalam mata pelajaran yang di ebtanaskan, $61,3 \%$ mengalami kesulitan dalam menulis dan 48,6\% mengalami kesulitan dalam berhitung. Siswa-siswa tersebut mengalami masalah dalam bidang akademik dan memerlukan layanan pendidikan khusus. Jika anak berkesulitan belajar tersebut tidak mendapatkan layanan khusus bisa kita bayangkan saja berapa banyak siswa yang akan terancam tinggal kelas bahkan beresiko tinggi bisa putus sekolah.

Menurut Lerner $40 \%$ dari anak berkebutuhan khusus yang memperoleh layanan PLB di Amerika Serikat ialah anak-anak yang tergolong berkesulitan belajar. Perbandingan proporsi mereka antara anak laki-laki dengan anak perempuan adalah 72 berbanding 78. Data tersebut menunjukkan bahwa kesulitan belajar lebih banyak terjadi pada anak laki-laki dari pada anak perempuan.

Hasil penelitian ini jika dibandingkan dengan penelitian oleh Tarmansyah memang berbeda. Prevalensi kesulitan belajar pada penelitian ini lebih tinggi dari Tarmansyah yang hanya $11,28 \%$, sedangkan prevalensi kesulitan belajar dari hasil penelitian ini berjumlah 26 , $2 \%$ Namun hasil penelitian ini mendukung penelitian yang dilakukan oleh Lerner yang mengatakan bahwa kesulitan belajar lebih banyak terjadi pada anak laki-laki dari pada anak perempuan. Data menunjukkan bahwa $27(64 \%)$ orang responden laki-laki mengalami kesulitan belajar, sedangkan responden perempuan separohnya 14 orang (33\%). Penelitian ini juga sama dengan penelitian yang dilakukan oleh Kahuziko bahwa prevalensi kesulitan belajar lebih banyak terjadi pada responden laki-laki, yang mana temuan Kahuziko menunjukkan prevalensi kesulitan belajar responden laki-laki dan perempuan adalah 4 berbanding satu.

Hasil penelitian ini juga menunjukan bahwa tidak ada perbedaan prevalensi kesulitan belajar responden berdasarkan tempat tinggal. Dimana pun responden tinggal apakah di rumah orang tua sendiri, tinggal di kostsan, tinggal di rumah saudara atau di asrama tidak memberikan perbedaan yang signifikan terhadap tingkat kesulitan belajar yang dialami.

\section{Simpulan dan Saran}

Berdasarkan hasil analisis data maka penelitian ini dapat disimpulkan bahwa prevalensi kesulitan belajar di Madrasah Aliyah Negeri I Bandar Lampung sebesar 26, 2\%. Prevalensi kesulitan belajar lebih banyak terjadi pada peserta didik laki-laki dari pada peserta didik perempuan. Sedangkan Tempat tinggal peserta didik dan jurusan tidak menentukan prevalensi kesulitan belajar. Boleh dikatakan bahwa tempat tinggal dan jurusan peserta didik tidak menunjukkan perbedaan prevalensi kesulitan belajar yang dialami oleh peserta didik tersebut.

Pihak sekolah: baik kepala sekolah, guru kelas, guru bidang studi maupun guru bimbingan konseling agar lebih memperhatikan proses pembelajaran peserta didik lakilaki.Perlu pendekatan khusus kepada peserta didik laki-laki untuk lebih jauh mengenali dan melihat apa sesungguhynya yang terjadi terhadap peserta didik yang mengalami kesulitan belajar.Perlunya pemberdayaan lebih maksimal guru-guru bimbingan dan konseling oleh Kepala Madrasah dalam rangka memberikan bantuan khusus terhadap anak-anak yang 
mengalami kesulitan belajar. Perlu dilakukan diagnosis lebih intensif kepada anak yang mengalami kesulitan belajar, sehingga bisa disusun program-program khusus untuk peserta didik yang mengalami kesulitan belajar.

\section{Daftar Pustaka}

Abdurrahman, M. (2012). Anak Berkesulitan Belajar. Jakarta: PT Rineka Cipta.

Brophy, J. (1999). Toward a model of the value aspects of motivation in education: Developing appreciation for particular learning domains and activities. Educational Psychologist. https://doi.org/10.1207/s15326985ep3402_1

Corey, G. (2013). Theory and practice of counseling and psychotherapy. Theory and Practice of Counseling and Psychotherapy 5th Ed. https://doi.org/10.1016/0022-3999(94)901236

Creswell, J. W. (2007). Research Design: Qualitative, Quantitative and Mixed Method Aproaches. SAGE Publications. https://doi.org/10.4135/9781849208956

Emzir, E. (2004). Metodologi Penelitian Pendidikan Kuantitatif \& Kualitatif. Jogyakarta: Gadjah Mada University Press.

Muhibbin, S. (2005). Psikologi Belajar. Jakarta: Raya Grafindo Perkas.

Yusuf, M. (2014). Metode Penelitian Kuantitatif, Kualitatif \& Gabungan. Jakarta: Prenadamedia Group. 